\title{
COVID-19 pandemic: educational technology for post- hematopoietic stem cell transplant patients
}

\author{
Pandemia da COVID-19: tecnologia educacional para pacientes pós-transplante de células tronco hematopoéticas
}

Pandemia de COVID-19: tecnología educativa para pacientes con trasplante de células madre hematopoyéticas

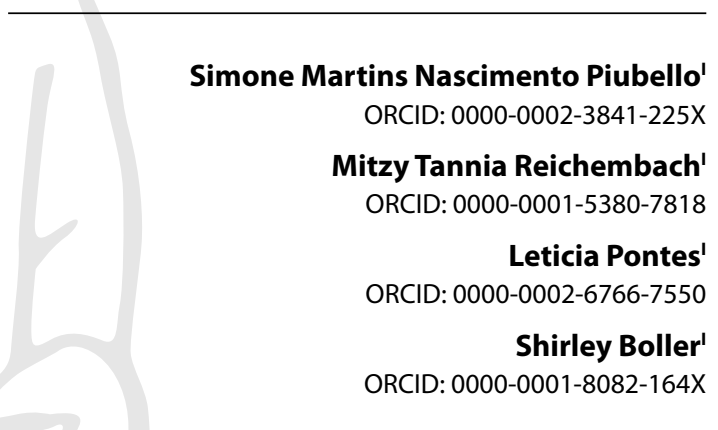

'Universidade Federal do Paraná. Curitiba, Paraná, Brazil.

How to cite this article: Piubello SMN, Reichembach MT, Pontes L, Boller S. COVID-19 pandemic: educational technology for posthematopoietic stem cell transplant patients. Rev Bras Enferm. 2021;74(Suppl 1):e20201088. https://doi.org/10.1590/0034-7167-2020-1088

Corresponding author: Simone Martins Nascimento Piubello E-mail: snpiubello@gmail.com

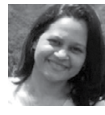

EDITOR IN CHIEF: Dulce Barbosa ASSOCIATE EDITOR: Elisabete Salvador

Submission: 09-16-2020

Approval: 02-19-2021

\begin{abstract}
Objective: to describe the experience of building the technology "Care for the prevention of COVID-19 in post-hematopoietic stem cell transplant patients". Methods: experience report conducted in a hematopoietic stem cell transplant outpatient clinic that supported the construction of an educational technology in the form of a booklet for the prevention of COVID-19. In May 2020, a literature review in scientific databases and guidelines of health organizations were used for its development. Results: printed booklet with information on the definition of coronavirus, hand hygiene, use of the mask by the patient and caregiver, isolation and social distancing and general hygiene care. Final Considerations: the use of technologies is characterized as a tool for educational actions therefore, nurses, patients and caregivers benefit from guidance processes for health care. The developed technology has the potential to minimize the impact and spread of SARS-CoV-2 among high-risk populations. Descriptors: Technology; Health Education; Coronavirus Infections; Hematopoietic Stem Cell Transplantation; Self Care.
\end{abstract}

\section{RESUMO}

Objetivo: descrever a experiência da construção da tecnologia "Cuidados para prevenção da COVID-19 em pacientes pós-transplante de células tronco hematopoéticas". Métodos: relato de experiência realizada em um ambulatório de transplante de células tronco hematopoéticas, que subsidiou a construção de tecnologia educacional do tipo cartilha para prevenção da COVID-19. Para o desenvolvimento, utilizou-se de revisão de literatura em bases de dados científicas e diretrizes de organizações de saúde, em maio de 2020. Resultados: cartilha impressa com informações referentes à definição do coronavírus, higiene das mãos, uso da máscara pelo paciente e cuidador, isolamento e distanciamento social e cuidados gerais de higiene. Considerações Finais: o uso de tecnologias se caracteriza como ferramenta para ações educativas, logo, enfermeiros, pacientes e cuidadores se beneficiam dos processos de orientação para cuidados à saúde. A tecnologia desenvolvida tem potencial para minimizar o impacto e disseminação do SARS-CoV-2 entre população de alto risco.

Descritores: Tecnologia; Educação em Saúde; Infecções por Coronavírus; Transplante de Células-Tronco Hematopoéticas; Autocuidado.

\section{RESUMEN}

Objetivo: describir la experiencia de construir la tecnología "Atención para la prevención de COVID-19 en pacientes postrasplante de células madre hematopoyéticas". Métodos: relato de experiencia realizado en un ambulatorio de trasplante de células madre hematopoyéticas que apoyó la construcción de una tecnología educativa tipo folleto para prevenir la COVID-19. Se utilizó una revisión de la literatura en bases de datos científicas y guías de organizaciones de salud en mayo de 2020. Resultados: cartilla con información sobre la definición de coronavirus, higiene de manos, uso de la mascarilla por paciente y cuidador, distanciamiento social y cuidados de higiene general. Consideraciones Finales: el uso de tecnologías es una herramienta para las acciones educativas que beneficia a enfermeros, pacientes y cuidadores en los procesos de orientación para el cuidado de la salud. La tecnología desarrollada tiene el potencial de minimizar el impacto y la propagación del SARS-CoV-2 entre las poblaciones de alto riesgo. Descriptores: Tecnología; Educación en Salud; Infecciones por Coronavirus; Trasplante de Células Madre Hematopoyéticas; Autocuidado. 


\section{INTRODUCTION}

The emergence of the new coronavirus (COVID-19) led to the occurrence of several cases of pneumonia in the city of Wuhan, People's Republic of China, in late 2019. COVID-19 spread rapidly throughout China and in February 2020, Brazil had the first reported cases. With the exponential increase in the number of infected people, the World Health Organization (WHO) declared a COVID-19 pandemic in March 2020(1).

This disease has several clinical reactions of asymptomatic infection or mild to moderate and severe forms that require oxygen support. Fever, fatigue, dry cough and dyspnea are the most frequent symptoms, sometimes followed by palpitations, myalgia, headache or diarrhea ${ }^{(2)}$.

Given the rapid spread and global impact of COVID-19, with increasing rates of hospitalizations and mortality in a population susceptible to the virus, and given the lack of available vaccines or specific effective antivirals, the COVID-19 pandemic represents a potential problem for public health and the health system.

The population at high risk for contracting the infection is diabetic, hypertensive, obese, immunocompromised, people infected by the Human Immunodeficiency Virus (HIV), pregnant women and cancer patients. A study with cancer patients and COVID-19 infection warned that this public is at high risk of developing serious clinical events and have a higher mortality rate due to the disease ${ }^{(2)}$. The population of Hematopoietic Stem Cell Transplant (HSCT) recipients deserves special attention, since these are immunocompromised patients ${ }^{(3)}$ either as a consequence of treatment or because of the underlying disease associated with the treatment.

There is still no official number of transplant patients who have contracted COVID-19, as they often have symptoms related to the upper respiratory tract that require rigorous assessment of symptoms. Among immunocompromised patients, the differential diagnosis of fever and respiratory symptoms is wide, given the possibility of alternative or secondary infections, including bacterial, fungal or other viral infections. The recognition and early treatment of bacterial sepsis remains vital, especially in neutropenic patients ${ }^{(4)}$.

Nursing has the important attributions of care and education in health. In settings such as stem cell transplant centers, nurses have faced challenges in guiding patients towards self-care, given the high number of care actions required by this therapeutic modality.

The HSCT outpatient clinic is a national reference in this therapeutic modality and assists patients in the post-stem cell transplant period. In other words, despite the successful engraftment in these patients, they are still immunocompromised by the use of immunosuppressants for prevention of Graft Versus Host Disease (GVHD), therefore, more susceptible to different types of infections ${ }^{(2)}$.

There is a growing concern among patients undergoing HSCT and family members about measures to be taken for COVID-19 prevention. Given the lack of specific drugs for treatment and vaccines to prevent this disease, frequent hand hygiene, care when coughing and sneezing, social distancing and the early treatment of suspected or confirmed cases are considered the main forms of prevention ${ }^{(5-6)}$.

These facts motivated the construction of a technology to guide patients and caregivers regarding care for the prevention of COVID-19. Videos, albums, booklets, games, websites and software are some of the existing educational technologies that serve as support in health education activities ${ }^{(7)}$. Printed booklets are a viable strategy for care promotion in emergency situations such as the COVID-19 pandemic, considering its low cost, as it is a printed resource.

\section{OBJECTIVE}

To describe the experience of building the educational technology entitled "Care for the prevention of COVID-19 in posthematopoietic stem cell transplant patients", for outpatients and their caregivers in a Bone Marrow Transplant Service.

\section{METHODS}

This is an experience report about the construction of an educational technology to guide patients undergoing $\mathrm{HSCT}$ and caregivers in relation to the prevention of COVID-19. The first step for the development of the proposal was a literature review performed in May 2020. An advanced search form was used in the following databases: Public Medline (PubMed), Cumulative Index to Nursing \& Allied Health Literature (CINAHL), Web of Science, Embase, MEDLINE complete, Cochrane library and Virtual Health Nursing Library (VHL).

This review comprised six steps namely, definition of the study question; delimitation of inclusion and exclusion criteria; data search; analysis of data and results; interpretation of results; and synthesis of the review with the purpose of answering the study question: what guidelines regarding COVID-19 are necessary for the patient after hematopoietic stem cell transplantation?

After reviewing the literature, seven primary studies from year 2020 were selected. Of these, three were from the United States of America, three from Europe and one from Australia, available in English. Then, after surveying the care practices found in primary studies, other information was sought on websites of national and international institutions: World Health Organization (WHO), Ministry of Health of Brazil (MS), Center for Disease Control and Prevention (CDC), European Society for Blood and Marrow Transplantation (EBMT) and Brazilian Society of Bone Marrow Transplantation.

After reading the articles and the content of the aforementioned websites, the main care practices for patients undergoing HSCT regarding the coronavirus were listed. Subsequently, a script was developed from the literature findings with the purpose of guiding the creation of the booklet. In this step, the topics to be addressed were described.

After preparing the script, the images for illustration were selected on Pixabay and Google Image free of charge. Informative texts were also prepared. After selecting the image and building the text, the booklet was developed with use of Canva, a graphic design platform for the creation of social media graphics, presentations, posters and other visual content. For editing the booklet, a flyer template was used, incorporating the League spartan font for titles in size 36; subtitles in size 32; and for the text, Inter font size 26 . The booklet includes 18 pages with the cover and a page of references and credits. 


\section{RESULTS}

The motivation to assist patients undergoing HSCT and caregivers regarding the prevention of COVID-19 allowed the construction of an educational technology in the form of a booklet addressing issues that contribute to a better understanding of the disease and preventive measures.

Two aspects are addressed: 1) what the coronavirus is - succinct presentation of the coronavirus and its main symptoms; 2 ) the preventive behaviors for COVID-19:

- Frequent hand hygiene: The most evidence-based measure and the main mechanism for preventing the spread of microorganisms, both in the community and in health services ${ }^{(8-9)}$. It is the most effective and least costly way to prevent nosocomial infections ${ }^{(10)}$. Hand hygiene can be performed with soap and water or $70 \%$ alcoholic solution. The booklet addresses the importance of this measure and the correct way to perform hand hygiene, using a step by step.

- Use of the mask:The mask limits the virus spread and prevents the inhalation of microorganisms by the patient ${ }^{(9-10)}$. The patient must use the surgical mask and the family member, the cloth mask. The booklet also guides you on the correct way to put the mask on and how to care for the cloth mask.

- Cough etiquette: Prevents virus transmission by contaminated hands, when touching on surfaces, preventing the virus spread to other people $\mathrm{e}^{(1,8)}$. Cover the nose and mouth with the inside of the elbow bent or a paper tissue and then, throw the tissue away and clean hands.

- Social distancing: The 1.5-meter distance between the patient and people other than the caregiver prevents that droplets from coughing, sneezing or talking, which can contain viruses, are launched into the air. Failure to keep the minimum distance may cause the individual to breathe the droplets, including the COVID-19 virus if the person has the disease ${ }^{(1)}$. The isolation limits spread, considering that the virus has a limited spatial reach ${ }^{(8-10)}$. The patient should not go to the market, pharmacy or other commercial establishments. The caregiver is the most suitable to perform activities that require leaving home, but recommendation is to go out as little as possible, thereby reducing the risk of contamination.

- Household hygiene and coming home from the street: It is essential to keep the house clean and ventilated. Disinfect surfaces constantly, such as tables, handles, light switches, tables, bathrooms, taps and sinks. Bags and articles purchased at markets or other establishments in addition to personal items taken to the street, such as wallets, cell phones, tablets and keys, must also be disinfected when getting home. Disinfect with $70 \%$ alcohol or sodium hypochlorite at a concentration of $0.1 \%$ to $0.5 \%$, which is equivalent to a $200 \mathrm{ml}$ glass for five liters of water for surfaces and objects. For fruits and vegetables, use two tablespoons of bleach for each liter of water. The solution must be stored in opaque packaging that prevents contact with sunlight ${ }^{(9-10)}$. Remove clothes and shoes before entering the house, as one of the main means of contagion is through hand contact with contaminated surfaces and subsequently, the hand contact on the face, conjunctiva and mucous membranes.

These guidelines are described on the 18 pages of the booklet together with the defined layout (Figure 1).

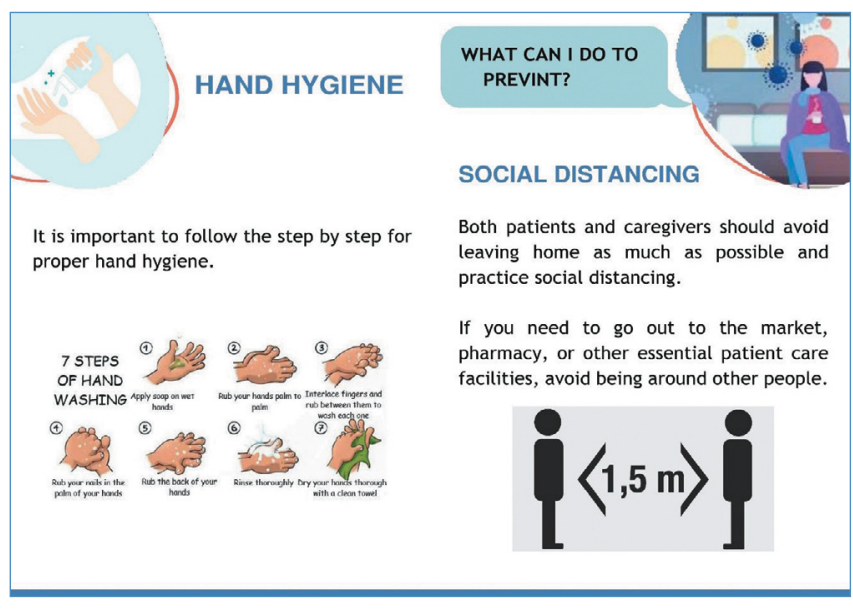

Figure 1 - Example of the layout of the COVID-19 prevention care guidance booklet for post-hematopoietic stem cell transplant patients

\section{Application of technology in the Bone Marrow Transplant Service outpatient clinic}

The Bone Marrow Transplant Service outpatient clinic serves post-HSCT patients. These patients are discharged from the hospitalization sector after the successful engraftment and continue outpatient follow-up usually until completing the $100^{\text {th }}$ day after transplantation, when they are discharged from hospital.

As these patients are undergoing recovery and outpatient follow-up, they need to travel daily or weekly to the hospital thus, they may get in contact with other people during the journey or even in the hospital environment with other patients and health professionals. Consequently, patients and caregivers had doubts about how to avoid the disease and care actions for self-protection.

The technology developed with guidelines for these patients is made available to patients and companions. A reading is performed with a nurse so they can clarify any doubts. The educational intervention occurs individually and is focused on the patient and the caregiver.

Patients and companions had doubts regarding patients not being allowed to wear a cloth mask, considering the higher cost of surgical masks and its shortage in pharmacies and hospital product shops. This shows the importance of nurses using strategies to provide basic guidance to these patients with the use of educational technologies. Another frequent question was related to correct hand hygiene, an action addressed in the booklet with guidance on the importance and correct form of hygiene.

Although general guidelines recommendations such as cleaning the house are provided by the service regardless of the pandemic, instructions on cleaning the house, cell phones, tablets, and removing shoes and clothes when entering the house to avoid contamination of surfaces in the domestic environment had to be intensified. 
The creation of this technology and the individual approach, in which patients are free to resolve doubts, are new measures implemented in the HSCT outpatient clinic for the containment and prevention of COVID-19 inside and outside the hospital environment, reducing these patients'insecurity in the pandemic period.

\section{Study limitation}

The booklet was made available to patients without content and face validation by experts and the target audience given the urgency of its implementation in the service.

\section{FINAL CONSIDERATIONS}

The high rate of transmissibility of COVID-19 requires that health professionals use technological innovations to effectively guide patients, especially those at risk, such as post-HSCT patients.

The developed technology has the potential to minimize the impact and spread of COVID-19 among high-risk populations, in addition to facilitating the teaching-learning process.

These evidence-based measures must be updated according to national and international epidemiological and health reference bodies.

\section{REFERENCES}

1. World Health Organization (WHO). Coronavirus disease (COVID-19) pandemic [Internet]. Geneva: WHO. 2020[cited 2020 Jun 20]. Available from: https://www.who.int/emergencies/diseases/novel-coronavirus-2019

2. Sica A, Casale D, Rossi G, Casale B, Cicozzi M, Fasano M, et al. The impact of the SARS-CoV-2 infection, with special reference to the hematological setting. J Med Virol. 2020;97(1):223-33. https://doi.org/10.1002/jmv.26197

3. Kamal KS, Jindal V, Siddiqui AD, Cerny J. Facing COVID-19 in the hematopoietic cell transplant setting: a new challenge for transplantation physicians. Blood Cells. 2020;83(102439). https://doi.org/10.1016/j.bcmd.2020.102439

4. Weinkove R, McQuilten ZK, Adler J, Agar MR Blyth E, Cheng AC, et al. Managing hematology and oncology patients during the COVID-19 pandemic: interim consensus guidance. Med J Aust. 2020;212(suppl10):481-9. https://doi.org/https://doi.org/10.5694/mja2.50607

5. Ministério da Saúde (BR). Secretaria de Atenção Especializada à Saúde. Departamento de Atenção Especializada e Temática. CoordenaçãoGeral do Sistema Nacional de Transplantes. Nota Técnica n 25/2020 [Internet]. Brasília: MS; 2020[cited 2020 Jul 26]. Available from: https:// antigo.saude.gov.br/images/pdf/2020/marco/26/Nota-Tecnica-Criterios-Tecnicos-para-triagem-clinica-do-coronavirus-SARS-MERS-SARSCoV-2-candidatos-a-transplantes.pdf

6. Ministério da Saúde (BR). Plano de Contingência Nacional para Infecção Humana pelo novo Coronavírus COVID-19 [Internet]. Brasília: MS; 2020 [cited 2020 Jun 30]. Available from: https://portalarquivos2.saude.gov.br/images/pdf/2020/fevereiro/13/plano-contingenciacoronavirus-COVID19.pdf

7. Leite SS, Áfio ACE, Carvalho LV, Silva JM, Almeida PC, Pagliuca LMF. Construction and validation of an Educational Content Validation Instrument in Health. Rev Bras Enferm. 2018:71(suppl 4):1635-41. https://doi.org/10.1590/0034-7167-2017-0648.

8. Cruz ED de A. Facing coronavirus - the triad of reverse protection: by protecting myself, I protect the other, by protecting the other, I protect myself. Cogitare Enferm. 2020;25:e73708. https://doi.org/10.5380/ce.v25i0.73708

9. Centers for Disease Control and Prevention. Cleaning and Disinfecting Your Home [Internet]. United States: CDC. 2020[cited 2020 Jun 30]. Available from: https://www.cdc.gov/coronavirus/2019-ncov/prevent-getting-sick/index.html

10. Agencia Nacional de Vigilância Sanitária (Anvisa). Nota Técnica $n^{\circ} 47$ de 15 de maio de 2020: Recomendações sobre produtos saneantes que possam substituir o álcool 70\% e desinfecção de objetos e superfícies, durante a pandemia de COVID19 [Internet]. Brasília: ANVISA; 2020[cited 2020 Jul 2]. Available from: https://www.gov.br/anvisa/pt-br/arquivos-noticias-anvisa/586json-file-1 